\title{
Persepsi Wisatawan Terhadap Citra Kepariwisataan Di Kawasan Titik Nol Kilometer Yogyakarta Pasca Revitalisasi
}

\author{
Aisha Astriecia a, 1, Nararya Rahadyan Budiyono b, 2 \\ 1 aisha.astriecia@gmail.com 1,2nararya@uty.ac.id \\ a Program Studi D4 Destinasi Pariwisata, Fakultas Humaniora, Pendidikan, dan Pariwisata, Universitas Teknologi Yogyakarta, Jl. Siliwangi, \\ Ringroad Utara, Sleman DIY, 55285 \\ b Program Studi S1 Bimbingan dan Konseling, Fakultas Humaniora, Pendidikan, dan Pariwisata, Universitas Teknologi Yogyakarta, Jl. Siliwangi, \\ Ringroad Utara, Sleman DIY, 55285
}

\section{Abstract}

Zero Kilometre Yogyakarta is one of the tourism destination icons of Yogyakarta. From visitors' perspectives, this destination is claimed to be the most unique one in Yogyakarta due to the multifunctional usages of the spot. Furthermore, Zero Kilometre Yogyakarta is not only used as a cultural destination, but also utilized as an interesting public space in the city. The present study aims to delineate the visitors' perceptions about the Zero Kilometre as one of Yogyakarta's tourist destination icons after its revitalization project. For this purposes, observation, questionnaires, and interviews were used as the data collection techniques. Moreover, the Slovin formula was utilized to determine 100 participants (57 woman and 43 men) who were randomly selected in the present study. As the data is the in form of quantitative, then the differential semantic charts were utilized for further analysis. The findings of the present study indicate that the visitors 'perceptions about Zero Kilometre Yogyakarta 56 percent of respondent stated this area as Zero Kilometre Yogyakarta. Data from semantic differential graphic also shown positive line tendential. In fact, the revitalization project brings about positive perceptions among the visitors as they view the project has made the Zero Kilometre Yogyakarta as the most interesting spot as one of cultural tourism destinations in town.

Keyword: perception, tourist, destination, image, culture

\section{PENDAHULUAN}

Titik Nol Kilometer Yogyakarta (yang selanjutkan akan disebut sebagai Titik Nol) merupakan pusat kota dan sering dijadikan tempat singgah para wisatawan setelah berwisata ke Malioboro, Keraton, maupun destinasi lainnya. Namun, tidak sedikit pula wisatawan yang memang sengaja datang ke lokasi ini untuk menikmati suasana Kota Jogja. Wisatawan yang datang untuk menikmati suasana di kawasan Titik Nol biasa dimulai pada sore sampai malam hari. Keberadaan wisatawan dalam jumlah besar di destinasi ini turut mendatangkan sejumlah pedagang, baik pedagang oleh-oleh maupun makanan dan minuman.

Kawasan Titik Nol Yogyakarta merupakan salah satu fokus penataan kawasan yang menjadi satu bagian dengan kawasan Malioboro. Di dalam rencana penataan kawasan Malioboro, kawasan Titik Nol menjadi sasaran penataan kedua setelah Alun-alun Utara. Rencana penataan kawasan tersebut direncanakan selesai tahun 2021 sebagai kawasan pedestrian. Pada tahun 2019 simpang empat Titik Nol sudah dapat dinikmati wisatawan dengan estetika yang unik. Sebelum dilakukannya revitalisasi, Titik Nol telah menarik kedatangan wisatawan cukup tinggi. Hal tersebut dapat terlihat langsung ketika melewati kawasan tersebut. Namun, besarnya kunjungan wisatawan juga membawa dampak negatif.

Pada saat pagi hari, kawasan ini terlihat bersih dan indah untuk dipandang. Namun menjelang sore sampai malam hari, wisatawan mulai meluap dan suasana di kawasan ini pun terasa perubahannya. Pelataran kawasan Titik Nol yang merupakan kawasan pedestrian mulai dipenuhi oleh sampah. Tumbuhan dan pohon yang difungsikan sebagai tempat duduk juga tidak luput dari sampah. Dampak yang kekumuhan yang terjadi sebagai akibat dari banyaknya kedatangan wisatawan juga disebabkan oleh kedatangan pedagang liar. Sampah-sampah yang terdapat di pelataran diakibatkan oleh sisa-sisa bungkus makanan dari pedagang. Padahal, tempat sampah telah disediakan di beberapa titik dan tempat sampah yang tersedia jarang terlihat penuh. Selain itu, muncul pula pengamen berpakaian preman yang mendatangi wisatawan yang sedang menikmati suasana di kawasan Titik Nol.

Revitalisasi kawasan Titik Nol dilakukan guna meningkatkan kenyamanan wisatawan untuk menikmati suasana Kota Jogja. Penataan kawasan tersebut cukup membuat kawasan ini terihat lebih bersih dengan melakukan pembongkaran tiang-tiang di sisi barat, penambahan kantong sampah, dan penempatan kursi taman di ruang terbuka. Sebelum dilakukannya revitalisasi, kawasan ini belum 
memiliki citra yang kuar sebagai salah satu destinasi wisata (Astriecia, 2016), namun kawasan ini telah memiliki citra sebagai kawasan budaya dengan adanya bangunan tua seperti Benteng Vredenburg dan Monumen SO 1 Maret (Aji, 2016).

Berdasarkan penyusunan rencana pengembangan kawasan Titik Nol, fungsi kawasan ini selain sebagai kawasan wisata, Titik Nol juga merupakan ruang terbuka kawasan publik sehingga tidak jarang kawasan ini dijadikan sebagai tempat pertemuan komunitas ataupun pengadaan kegiatankegiatan tertentu. Berdasarkan penelitianpenelitian yang telah dilakukan sebelumnya dengan lokasi penelitian di Titik Nol, penelitian ini akan mengaji persepsi wisatawan terhadap kondisi kepariwisataan pasca dilakukannya revitalisasi. Hal tersebut bertujuan untuk melihat ada atau tidaknya perubahan persepsi pengunjung ataupun wisatawan setelah dilakukannya penataan kawasan.

Penelitian terkait persepsi wisatawan di Titik Nol pernah dilakukan pada tahun 2016 atau sebelum revitalisasi yang menunjukkan bahwa kawasan ini belum dipersepsikan dengan kuat sebagai ikon destinasi wisata di Yogyakarta (Astriecia, 2016). Penelitian lain dengan lokus yang sama lebih mengarah pada sudut pandang keruangan menjelaskan mengenai walkability di kawasan tersebut dan menyatakan bahwa Titik Nol memiliki walkability yang kurang baik dikarenakan bangunan ada di kawasan ini tidak terhubung langsung, sehingga dominasi penggunaan sepeda motor untuk menjangkau antar bangunan tinggi (Nugrahaini, 2019), walaupun penelitian lain telah memosisikan Titik Nol sebagai kawasan publik yang memuat berbagai aktivitas sosial (Wardhani, 2018). Penelitian terkait persepsi terhadap citra kawasan di Titik Nol terutama setelah revitalisasi belum pernah dilakukan dan dinilai penting karena Titik Nol merupakan salah satu ikon wisata di Yogyakarta.

\section{TINJAUAN PUSTAKA}

Destinasi wisata budaya merupakan destinasi wisata dengan budaya sebagai daya tarik utamanya. Pitana dan Diarta (2005) menjabarkan bahwa sumber daya budaya yang dapat dikembangkan sebagai daya tarik wisata di antaranya bangunan bersejarah, situs, monumen, museum. Unsur yang terkait di dalam wisata budaya yang lain contohnya suasana. Komponen suasana biasa menjadi faktor daya tarik tambahan dalam suatu wisata budaya. Suasana juga dapat dijadikan sebagai unsur budaya karena suasana dapat menghasilkan perasaan yang berbeda bagi wisatawan.
Perasaan tersebut tersalurkan dari saluran inderawi yang utama manusia berupa pandangan, suara, bau, dan sentuhan (Kotler, Bowen, \& Makens, 2002). Saluran inderawi yang dapat menciptakan perasaan pada manusia berupa dimensi penglihatan (warna, kecerahan, ukuran, dan bentuk), dimensi pendengaran (volume, dan tinggi nada), dimensi penciuman (bau dan kesegaran), dan dimensi sentuhan (kelembutan, kehalusan, dan suhu) (Kotler, Bowen, \& Makens, 2002). Warna dalam sebuah ruang dapat menciptakan kesan yang beragam. Warna juga dapat mempengaruhi kualitas suatu ruang dan menjadikannya lebih luas atau bahkan lebih sempit dari ukuran asinya (Haryadi \& Setiawan, 2010). Sehingga warna ruang selain dapat mempengaruhi inderawi penglihatan, juga dapat mempengaruhi inderawi perasaan.

Destinasi wisata budaya memiliki beberapa komponen penting berupa atraksi atau daya tarik, fasilitas, dan aksesibilitas. Komponen atraksi merupakan daya tarik utama yang dapat mendatangkan wisatawan. Kedatangan wisatawan akan terasa lebih nyaman apabila pada sebuah destinasi wisata dilengkapi dengan fasilitas baik pasilitas umum maupun fasilitas pariwisata. Komponen aksesibilitas merupakan komponen yang tidak kalah penting karena merupakan faktor yang mempengaruhi kemudahan wisatawan sampai ke destinasi (Yoeti, 1982 dan Soekadijo, 1996).

Selain tiga komponen destinasi wisata di atas, destinasi wisata juga memiliki komponen lain yaitu perancangan seting atau tata ruang untuk menampung berbagai kegiatan wisata dan kesiapan destinasi untuk dikunjungi. Komponen ini juga menjadi faktor penentu kemenarikan destinasi dan daya tampung wisatawan. Komponen tersebut meliputi komponen yang bersifat fix/tetap (dinding, kolam, atap), komponen bersifat semi-fix/semi tetap (perabot), dan komponen bersifat non-fix/tidak tetap (warna, dekorasi, perilaku, dan suasana) (Haryadi \& Setiawan, 2010).

Gabungan komponen destinasi wisata dan tata ruang merupakan salah satu faktor yang dapat mempengaruhi pembentukan citra pada sebuah destinasi wisata. Citra destinasi wisata atau tourist destination image merupakan salah satu bentuk labelling yang tercipta secara sengaja maupun tidak. Citra destinasi bisa saja sengaja dibentuk oleh perancang usaha pariwisata saat merancang atau merevitalisasi sebuah destinasi wisata. Namun, citra tersebut dapat berubah akibat pengalaman yang disampaikan oleh wisatawan setelah melakukan kunjungan wisata. Citra yang terbentuk di pasar atau secara tidak sengaja merupakan gabungan 
antara berbagai faktor yang terdapat pada destinasi seperti cuaca, pemandangan alam, keamanan, kesehatan dan sanitasi, keramahtamahan, dan informasi yang diterima oleh calon wisatawan dari berbagai sumber di pihak lain atau fantasinya sendiri (Pitana \& Gayatri, 2005). Citra destinasi juga dapat terbentuk dari persepsi wisatawan berdasarkan pengalaman perjalanan secara individu. Sehingga elemen kognitif wisatawan menggiring citra keseluruhan destinasi terbentuk (Utama, 2017).

Persepsi dapat diartikan sebagai aktivitas pengelolaan informasi yang menghubungkan individu atau manusia dengan lingkungannya (Hanurawan, 2015) yang didahului oleh proses penginderaan (Walgito, 2003). Di saat proses pembentukan persepsi berlangsung, memori akan merinci masukan (input) untuk menemukan ciri tertentu pada suatu konsep (Hanurawan, 2015). Sebagaimana pendefinisian persepsi yang merupakan suatu proses yang didahului oleh proses penginderaan, yaitu merupakan proses diterimanya stimulus oleh individu melalui alat indera atau juga disebut proses sensoris guna memberikan arti bagi lingkungan manusia (Robbins \& Judge, 2009 dan Walgito, 2004). Pola pembentukkan persepsi tersebut berkaitan dengan stimulus-stimulus yang akan mempengaruhi respon atau reaksi manusia secara psikologis (Walgito, 2004). Faktor-faktor yang berperan dalam pembentukan persepsi tersebut meliputi objek yang dipersepsi, alat indera, syaraf, dan pusat susunan syaraf, dan perhatian

Persepsi lingkungan merupakan proses ketika manusia menerima informasi mengenai lingkungan sekitarnya dan bagaimana informasi mengenai ruang fisik tersebut diorganisasikan ke dalam pikiran manusia (Laurens, 2005). Haryadi dan Setiawan (2010) mendefinisikan persepsi lingkungan sebagai interpretasi tentang suatu tata ruang oleh seseorang, berdasarkan latar belakang budaya, nalar, dan pengalaman. Citra persepsi terhadap lingkungan sangat penting karena persepsi tersebut akan membentuk perilaku manusia di dalam lingkungan tersebut. Di dalam konteks lingkungan persepsi digunakan untuk menggambarkan evaluasi terhadap lingkungan yang di dalamnya termasuk persepsi terhadap kualitas lingkungan, perilaku, dan pengambilan keputusan (Rapoport, 1977). Manusia merupakan makhluk berpikir yang mempunyai persepsi dan keputusan dalam interaksinya dengan lingkungan. Kemudian Haryadi dan Setiawan (2010) mengutarakan proses terpersepsikannya lingkungan merupakan hasil dari proses kognisi, afeksi, dan kognasi. Proses kognisi meliputi proses penerimaan, pemahaman, dan pemikiran tentang suatu lingkungan. Proses afeksi, meliputi proses perasaan dan emosi, keinginan, serta nilai-nilai tentang lingkungan. Sedangkan proses kognasi, meliputi munculnya tindakan, perlakuan terhadap lingkungan sebagai respons dari proses kognisi dan afeksi.

\section{METODE PENELITIAN}

Lokasi penelitian berada di Kawasan Titik Nol Kilometer Yogyakarta dengan wilayah amatan diperluan mulai dari titik nol Malioboro sampai dengan Alun-alun Utara Yogyakarta. Lokasi fokus penelitian terletak di simpang empat Titik Nol Kilometer, lokasi tersebut juga dijadikan sebagai lokasi pengambilan data kuisioner. Metode pengumpulan data yang digunakan adalah observasi lapangan atau survei kondisi lokus penelitian, dan wawancara (Wardiyanta, 2010) (Nazir, 2014). Penentuan jumlah responden untuk pengisian kuisioner menggunakan perhitungan rumus Slovin (Umar, 2011) dengan jumlah populasi diasumsikan dari jumlah kunjungan wisatawan domestik ke Kota Yogyakarta dan toleransi kesalahan (margin eror) sebesar sepuluh (10) persen. Perhitungan tersebut menghasilkan jumlah responden 99,9 yang kemudian dibulatkan menjadi 100 responden. Teknik pengambilan sampel menggunakan nonrandom accidential sampling yang dilakukan kepada siapa saja yang ditemui pada lokus penelitian (Wardiyanta, 2010). Waktu penyebaran kuisioner dilakukan mulai pada sore sampai malam hari dan dilakukan pada hari kerja dan akhir pekan untuk mendapatkan varisasi data. Data yang diperoleh dari kuisioner akan diolah kedalam skala grafik semantic differential. Skala grafik semantic differential merupakan skala yang digunakan untuk mengukur konsep atau persepsi dari sebuah objek dalam suatu skala bipolar. Skala bipolar merupakan skala yang memiliki sifat yang berlawanan seperti baik-buruk. Penelitian ini menggunakan lima titik skala bipolar untuk melihat kecenderungan hasilnya (Nazir, 2014). Selain menggunakan pertanyaan dengan skala bipolar, penelitian ini juga menggunakan pertanyaan tertutup (Wardiyanta, 2010). Pertanyaan tertutup pada kuisioner bertujuan untuk melihat persepsi wisatawan secara deskriptif terhadap citra destinasi ,pemanfaatan fasilitas, dan penggunaan transportasi. Data tersebut kemudian akan dikorelasikan dengan hasil data berupa grafik. Hasil penelitian akan dianalisis secara deskriptif kuantitatif. Analisis menggunakan deskriptif kuantitatif merupakan bentuk analisis myang menjabarkan suatu fenomena sesua dengan keadaan sesungguhnya dan dengan diperkuat dengan data numerik (Hamdi \& Bahruddin, 2015).

\section{HASIL DAN PEMBAHASAN}


Proses analisis persespsi di dalam penelitian ini terbagi atas 2 bagian. Bagian pertama adalah persepsi yang berkaitan dengan penginderaan wisatawan. Bagian kedua adalah persepsi terkait komponen pariwisata. Persepsi terkait penginderaan meliputi penginderaan penglihatan, penciuman, pendengaran, dan perasaan. Sedangkan persepsi terkait pariwisata meliputi atraksi, fasilitas, dan aksesibilitas. Fasilitas yang menjadi penilaian wisatawan merupakan fasilitas yang terdapat pada area penelitian yaitu radius 100 meter di sekitar Kawasan Titik Nol Kilometer Yogyakarta.

Gambar I merupakan data persepsi wisatawan berdasarkan komponen penginderaan. Kriteria yang dinilai oleh responden meliputi kebersihan, kerapihan tata ruang, keindahan dari komponen penglihatan. Kriteria kesegaran udara dan tingkat polusi berasal dari penginderaan penciuman. Kriteria kebisingan dan kenyamanan berdasarkan komponen pendengaran. Kriteria kenyamanan, perasaan aman, dan senang dari komponen perasaan. Berdasarkan gambar I dapat dilihat bahwa berdasarkan penginderaan penciuman dan pendengaran merupakan komponen yang memiliki kecenderungan kriteria negatif yang lebih tebal dibandingkan dengan penginderaan penglihatan dan perasaan. Namun secara keseluruhan komponen penginderaan sudah mengarah pada kriteria positif dari persepsi wisatawan.

Kriteria penglihatan yang menjadi objek persepsi wisatawan atau responden berupa kondisi keruangan di Kawasan Titik Nol Kilometer. Kondisi keruangan tersebut berhubungan langsung dengan perubahan tata letak fasilitas, penerangan, keberadaan pedagang temporer, komunitas, dan sebaran atraksi temporer seperti badut karakter. Kriteria berdasarkan pendengaran wisatawan dipengaruhi oleh letak destinasi yang berada pada simpang empat jalanan kota serta hiruk pikuk yang berasal dari pedagang dan wisatawan lain. Kriteria penciuman diperoleh dari aktivitas wisatawan lain seperti adanya wisatawan yang merokok atau rokok elektrik dan polusi yang berasal dari kendaraan bermesin. Kriteria perasaan berasal dari gabungan ketiga kriteria sebelumnya yang menimbulkan perasaan yang berbeda setelah wisatawan mendapatkan pengalaman berkunjung pada lokus penelitian.

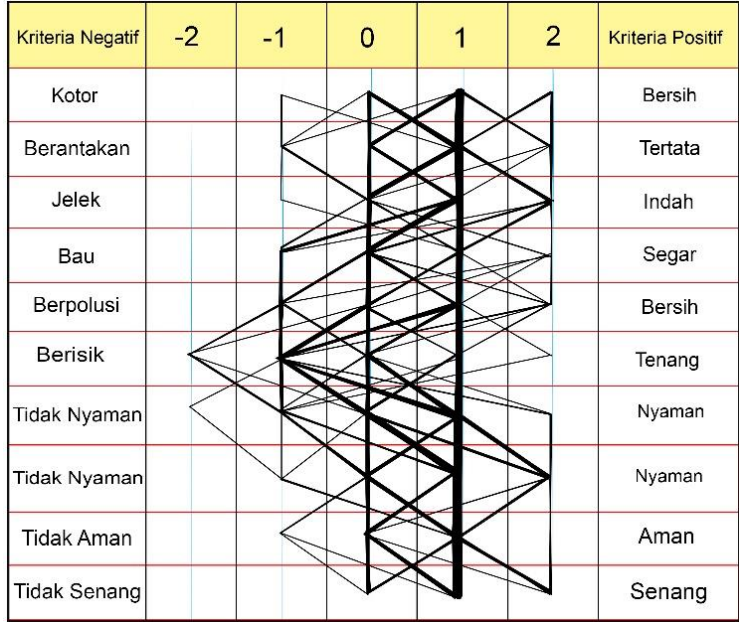

Gambar I. Grafik Komponen Penginderaan Sumber: hasil penelitian,2020

Komponen penilaian kedua berdasarkan aspek kepariwisataan. Gambar II merupakan hasil persepsi wisatawan terhadap aspek kepariwisataan di Kawasan Titik Nol Kilometer Yogyakarta. Kriteria penilaian pertama yang diambil berupa kemenarikan dan kondisi fisik atraksi wisata berdasarkan komponen atraksi wisata. Kriteria penilaian kedua berdasarkan komponen fasilitas berupa kelengkapan, kebersihan, dan kuantitas fasilitas di sekitar lokus. Kriteria penilaian ketiga berupa kemudahan wisatawan untuk sampai ke Kawasan Titik Nol Kilometer Yogyakarta. Berdasarkan Gambar II, komponen atraksi menjadi komponen dengan penilaian yang paling baik dibandingkan komponen fasilitas dan aksesibilitas. Responden atau wisatawan dengan persepsi yang cenderung negatif tidak mendominasi. Sedangkan untuk komponen fasilitas dan aksesibilitas memiliki sebaran hasil yang serupa. Masih terdapat responden yang berpersepsi kurang baik terhadap fasilitas dan aksesibilitas di Titik Nol Kilometer.

Komponen penilaian atraksi wisata di lokus penelitian meliputi suasana di Titik Nol Kilometer, bangunan cagar budaya, signage, atraksi temporer, dan keberadaan komunitas tertentu. Komponen penilaian berdasarkan kriteria fasilitas berupa persebaran tempat sampah, kemudahan menjangkau toilet, tempat ibadah, makanan dan minuman, dan persebaran tempat duduk. Komponen penilaian terakhir yang berasal dari kriteria aksesibilitas merupakan kemudahan wisatawan untuk menjangkau Titik Nol Kilometer Yogyakarta. 


\begin{tabular}{|c|c|c|c|c|c|c|}
\hline Kriteria Negatif & -2 & -1 & 0 & 1 & 2 & Kriteria Positif \\
\hline Jelek & & & & & & Bagus \\
\hline Membosankan & & & & & & Menarik \\
\hline Kurang Lengkap & & & & & & Lengkap \\
\hline Sedikit & & & & & & Banyak \\
\hline Kotor & & & & & & Bersih \\
\hline Sulit & & & & & & Mudah \\
\hline
\end{tabular}

Gambar II. Grafik Komponen Destinasi Wisata Sumber: hasil penelitian,2020

Hasil grafik komponen penginderaan berhubungan erat dengan grafik komponen suatu destinasi wisata, karena objek yang dipersepsikan oleh insur penginderaan berasal dari destinasi wisata yang disinggahi oleh wisatawan tersebut. Kawasan Titik Nol Kilometer Yogyakarta memeiliki daya tarik wisata yang berbeda dengan destinasi wisata budaya lainnya. Pada dasarnya sebuah destinasi wisata budaya merupakan destinasi yang menjadikan budaya menjadi daya tarik utamanya. Sedangkan Titik Nol memiliki persebaran bangunan cagar budaya yang menimbulkan atraksi baru berupa suasana. Kawasan ini identik dengan tempat untuk menikmati suasana Kota Jogja. Wisatawan yang mengunjungi destinasi cenderung menikmati suasana dengan cara duduk santai di pelataran kawasan. Oleh sebab itu revitalisasi kawasan ini dirancang lebih terbuka. Tata ruang di kawasan ini sebelum revitalisasi memiliki tingkat kepadatan yang lebih tinggi yang berasal dari komponen fisik permanennya seperti tugu eksibisi batik, tempat duduk, dan pohon-pohon besar (Astriecia, 2020). Kepadatan komponen fisik permanen tersebut mengakibatkan kawasan ini terlihat lebih ramai terutama pada saat akhir pekan. Kepadatan ruang tersebut juga dapat menciptakan perasaan yang berbeda pada wisatawan yang berada di dalamnya. Hal tersebut dikarenakan adanya ikatan kuat dari fungsional suatu ruang dengan aktivitas fisik manusia di dalamnya (Wardhani, 2018).

Keterkaitan tersebut juga terjadi di Kawasan Titik Nol apabila dilihat dari kedua grafik pada gambar I dan II. Kecenderungan pada gambar I dan II mengarah pada kriteria positif. Penelitian sebelumnya terkait persepsi wisatawan sebelum revitalisasi juga mengarah pada kriteria positif, namun hasil persepsi wisatawan terkait destinasi tersebut kurang kuat sebagai sebuah destinasi wisata (Astriecia, 2016). Sebelum dilakukannya revitalisasi di Kawasan Titik Nol Kilometer Yogyakarta citra destinasi sebegai sebuah tempat wisata hanya sebesar 30\% dan diperingkat kedua yaitu sebesar 25\% sebagai tempat nongkrong (Astriecia, 2016). Setelah revitalisasi citra di kawasan ini mulai berubah. Berdasarkan hasil kuisioner sebesar 56\% responden telah benar mempersepsikan kawasan ini sebagai Kawasan Titik Nol Kilometer Yogyakarta, sedangkan pada peringkat kedua sebesar 25\% sebagai Destinasi Wisata Malioboro, peringkat ketiga sebesar $17 \%$ sebagai Titik Nol Kilometer Malioboro, dan terakhir sebesar $2 \%$ sebagai ruang publik.

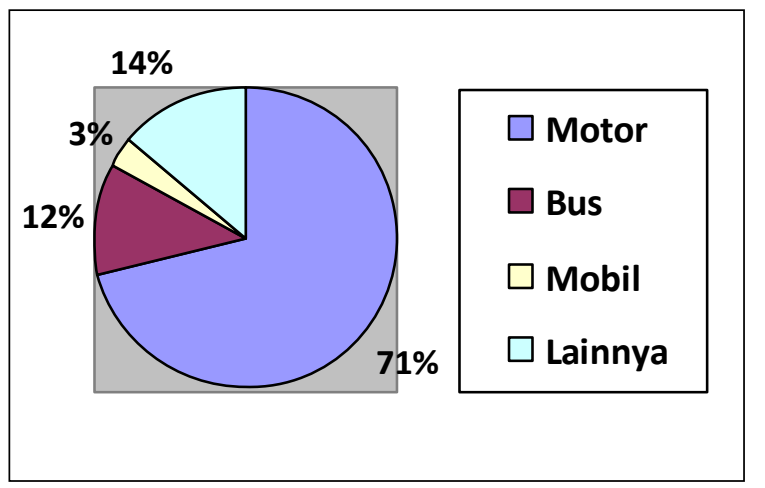

Gambar III. Transprotasi yang Digunakan Wisatawan Sumber: hasil penelitian,2020

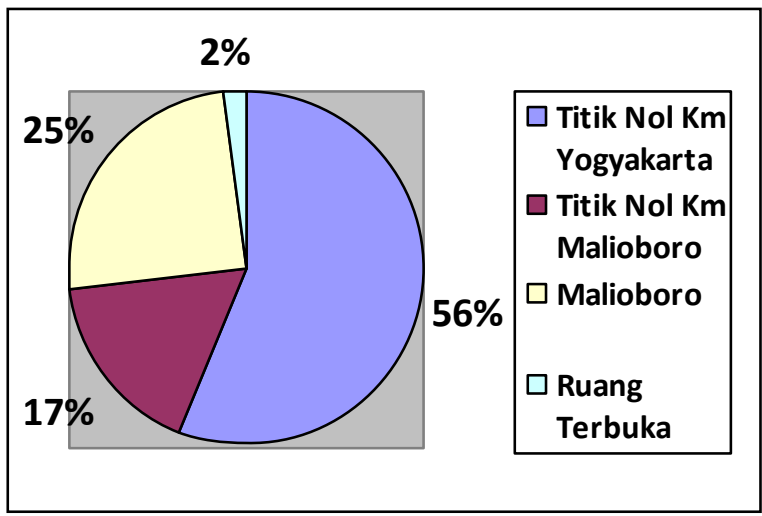

Gambar IV. Citra Titik Nol Menurut Persepsi Wisatawan

Sumber: hasil penelitian,2020

Apabila dilihat berdasarkan moda transportasi yang digunakan, wisatawan yang berkunjung ke kawasan ini sebanyak 74\% menggunakan transportasi motor sebelum revitalisasi (Astriecia, 2016). Hal tersebut tidak jauh berbeda setelah revitaslisasi sebesar 71\%. Pemanfaatan moda transportasi motor sesuai dengan karakterikstik kawasan yang memiliki kapasitas dan persebaran area parkir kendaraan bermotor yang lebih banyak. Komponen penilaian terakhir berupa atraksi yang dinikmati wisatawan. Atraksi berupa suasana memiliki peringkat tertinggi sebesar $60 \%$ dan diikuti oleh bangunan cagar budaya sebesar $29 \%$. 


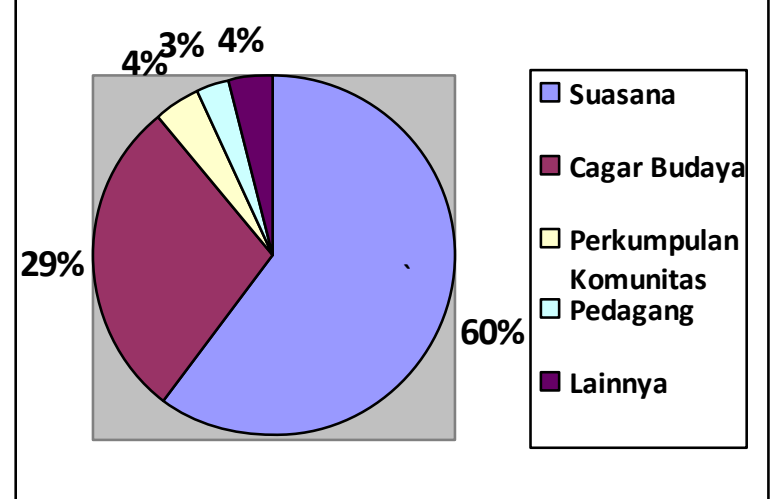

Gambar V. Atraksi yang dinikmati wisatawan Sumber: hasil penelitian,2020

Hasil grafik komponen destinasi pariwisata dan penginderaan memiliki kesinambungan dengan hasil pertanyaan terbuka. Aksesibilitas di kawasan ini baik dikarenakan sebagian besar wisatawan memggunakan transportasi motor. Hal tersebut juga sesuai dengan ketersediaan area parkir motor yang lebih banyak. Persepsi wisatawan terhadap kawasan sebagai Titik Nol Kilometer Yogyakarta sudah kuat sesuai dengan hasil grafik kedua gambar yang mengarah pada kriteria positif. Revitalisasi Kawasan Titik Nol yang berkonsep lebih terbuka dibanding sebelumnya juga menghasilkan tingkat kenyamanan lebih baik bagi wisatawan.

\section{KESIMPULAN}

Kawasan Titik Nol Kilometer Yogyakarta merupakan salah satu ikon pariwisata di Kota Jogja. Kawasan ini mengalami revitalisasi kawasan pada yang telah selesai sekitar tahun 2018. Tujuan revitalisasi kawasan ini salah satunya untuk meningkatkan kenyamanan wisatawan. Sehingga kawasan ini menghadirkan

\section{DAFTAR PUSTAKA/REFERENSI}

Astriecia, Aisha. (2016). Persepsi Wisatawan Domestik terhadap Kondisi Kepariwisataan di Kawasan Titik Nol Kilometer Yogyakarta. Thesis. Universitas Gadjah Mada: Yogyakarta.

Astriecia, A. (2020). Pengaruh Tata Ruang Terhadap Perilaku Wisatawan di Kawasan Nol Kilometer Yogyakarta. Sinektika: Jurnal Arsitektur., https://doi.org/10.23917/sinektika.v17i1.10834

Aji, Adam Whisnu. (2016). Sense of Place Kawasan Titik Nol Kilometer Yogyakarta. Thesis. Universitas Gadjah Mada: Yogyakarta

Hamdi, A. S., \& Bahruddin, E. (2015). Metode Penelitian Kuantitatif Aplikasi dalam Pendidikan. Yogyakarta: Deepublish.

Hanurawan, F. (2015). Psikologi Sosial: Suatu Pengantar. Bandung: Remaja Rosdakarya Offset.

Haryadi, \& Setiawan, B. (2010). Arsitektur, Lingkungan, dan Perilaku: Pengantar ke Teori, Metodologi dan Aplikasi. Yogyakarta: UGM Press.

Kotler, P., Bowen, J., \& Makens, J. (2002). Pemasaran Perhotelan dan Kepariwisataan (Vol 1). Jakarta: Pearson Education Asia dan Prenhallindo. tata ruang yang lebih terbuka dan tertata. Pelaksanaan revitalisasi di kawasan Titik Nol Kilometer Yogyakarta terbukti dapat meningkatkan kenyamanan wisatawan dalam menikmati suasana Jogja dan bangunan cagar budaya di sekitar kawasan. Revitalisasi juga telah memperkuat persepsi wisatawan terhadap citra kawasan sebagai salah satu destinasi wisata budaya di Yogyakarta. Hal tersebut dibuktikan dengan tingginya persepsi positif dari wisatawan baik berdasarkan penginderaan maupun komponen destinasi wisatanya.

Wisatawan di Titik Nol Kilometer Yogyakarta juga telah menyadari bahwa tempat yang disinggahinya merupakan Titik Nol Kilometer Yogyakarta. Pernyataan tersebut dapat dibuktikan dengan hasil penelitian yang menunjukkan lima puluh enam persen wisatawan menyadari destinasi tersebut sebagai Titik Nol Kilometer Yogyakarta. Apabila dilihat berdasarkan karakteristik penggunaan transportasi oleh wisatawan. Titik Nol merupakan destinasi wisata yang didominasi oleh pengguna kendaraan motor. Namun, revitalisasi yang dilakukan tidak merubah penggunaan transportasi untuk menuju destinasi ini. Sedangkan berdasarkan atraksi wisatanya, destinasi ini memiliki daya tarik suasana yang sangat tinggi. Sehingga alasan tersebut menjadi salah satu faktor datangnya wisatawan.

Berdasarkan hasil temuan pada penelitian ini, dapat disimpulkan bahwa revitalisasi yang dilakukan di destinasi wisata Titik Nol Kilometer Yogyakarta memperkuat citra destinasi sebagai salah satu destinasi budaya di Yogyakarta. Revitalisasi juga dinilai telah meningkatkan kenyamanan wisatawan dalam kegiatan wisata.

Laurens, J. M. (2005). Arsitektur dan Perilaku Manusia. Jakarta: Grasindo.

Nazir, M. (2014). Metode Penelitian. Bogor: Ghalia Indonesia.

Nugrahaini, F. T. (2019). WALKABILITY DI KAWASAN TITIK NOL KILOMETER YOGYAKARTA MELALUI SIMULASI URBAN MODELLING INTERFACE (UMI). Jurnal Arsitektur ARCADE. https://doi.org/10.31848/arcade.v3i1.197

Pearce, L. P. (2005). Tourist Behaviour: Themes and Conceptual Schemes. Great Britain: Cromwell Press.

Pitana, I. G., \& Gayatri, P. G. (2005). Sosiologi Pariwisata. Yogyakarta: ANDI.

Pitana, I. G., \& I Ketut Surya Diarta. (2009). Pengantar Ilmu Pariwisata. Yogyakarta: ANDI.

Purwanto, A. E., \& D, S. R. (2007). Metode Penelitian Kuantitatif Untuk Administrasi Publik dan Masalah-masalah Sosial Yogyakarta: Gava Media.

Rapoport, A. (1977). Human Aspects of Urban Form. New York: Pergamon Press.

Robbins, S. P., \& Judge, T. A. (2009). Perilaku Organisasi : (12 ed.) (D. Angelica, Trans.) Jakarta: Salemba Empat.

Soekadijo, R. G. (1996). Anatomi Pariwisata: Memahami Pariwisata Sebagai System Linkage. Jakarta: Gramedia Pustaka Utama 
Umar, H. (2011). Metode Penelitian untuk Skripsi dan Tesis Bisnis. Jakarta: Rajawali Press.

Utama, I. G. (2017). Pemasaran Pariwisata. Yogyakarta: ANDI.

Walgito, B. (2003). Psikologi Sosial: Suatu Pengantar. Yogyakarta: ANDI.

Walgito, B. (2004). Pengantar Psikologi Umum. Yogyakarta: ANDI.

Wardhani Kusumaning, M. (2018). TITIK NOL KILOMETER KOTA YOGYAKARTA SEBAGAI RUANG TERBUKA PUBLIK DITINJAU DARI DIMENSI FUNGSIONAL, SOSIAL, DAN VISUAL. Jurnal Planologi. https://doi.org/10.30659/jpsa.v15i1.2739

Wardiyanta. (2010). Metode Penelitian Pariwisata. Yogyakarta: ANDI.

Yoeti, O. A. (1982). Pengantar Ilmu Pariwisata. Bandung: Angkasa. 